\title{
Budjettikurisopimus - kestävään talouteen pakottaminen oikeuden keinoin
}

\section{Tomi Tuominen}

\begin{abstract}
Abstrakti
Julkisen talouden kestävyysvaje on noussut viime vuosina näkyväksi osaksi talouspolitiikkaa. Euroopan unionin Vakaus- ja kasvusopimuksen tiukentamiseksi tehty niin sanottu budjettikurisopimus pyrkii vastaamaan valtiontalouden kestävyysvajeeseen lisäämällä jäsenvaltioiden talouden "kestävyyttä". Vaikka kestävyyden sisältö on määritelty sopimuksessa objektiivisin kriteerein, ei tällä näytä olevan suurta käytännön merkitystä unionin talouspoliittisessa viitekehyksessä. Myös sopimuksen oikeudelliset mahdollisuudet budjettikurin lisäämiseksi vaikuttavat vähäisiltä. Sopimus edustaa uusliberaaliin politiikkaan perustuvaa uudeksi konstitutionalismiksi kutsuttua kehityskulkua, joka eristää politiikkaa taloudesta ja oikeudesta. Sopimuksen laajempi merkitys paljastuu, kun sopimusta tarkastellaan tämän viitekehyksen puitteissa. Sopimus voidaan ymmärtää yritykseksi naamioida tiettyjä poliittisia valintoja näennäisesti neutraaliin normatiivisuuden kaapuun. Se paljastaa myös Euroopan talous- ja rahaliiton nykyisen rakenteen todennäköisen kestämättömyyden.
\end{abstract}

Avainsanat: budjettikurisopimus, eurokriisi, Euroopan talous- ja rahaliitto, kestävyys, Vakaus- ja kasvusopimus, uusliberalismi, uusi perustuslaillisuus

\section{Johdanto}

Julkistalouden kestävyys, tai pikemminkin sen puute, on noussut viime vuosina yhdeksi talouspolitiikkaa keskeisesti määrittäväksi ideaksi. Tätä kestävyysvajeeksi käsitteellistettyä ilmiötä on luonnehdittu jopa jonkinasteiseksi ajanhengeksi, 2000-luvun Zeitgeistiksi (Sorsa 2014). Euroopan komission (2006a) näkemyksenä oli jo ennen eurokriisin alkua, että kestävyysvaje 
pystytään ehkäisemään jäsenvaltioiden julkistalouden budjettialijäämää ja velkataakkaa rajoittamalla. Kestävyyden lisääminen ja kestävyysvajeeseen puuttuminen vastaavalla tavalla on noussut myös osaksi eurokriisin ratkaisua. Kaikkia eurokriisin ulottuvuuksia on pyritty ratkaisemaan luomalla uusia oikeudellisia rakennelmia. Jäsenvaltioiden keskenään solmima niin sanottu budjettikurisopimus (Sopimus talous- ja rahaliiton vakaudesta, yhteensovittamisesta sekä ohjauksesta ja hallinnasta) pyrkii ratkaisemaan kriisivaltiot konkurssin partaalle ajaneet alijäämät ja velkataakat yksinkertaisesti säätämällä lain, joka rajoittaa niitä. ${ }^{1}$

Oikeudellisten rakenteiden käyttö osana kansainvälistä talouspoliittista hallintaa on yleistynyt tämän vuosituhannen aikana. Rakenteiden käyttö juontaa juurensa uusliberaaliin politiikkaan. Uusliberalismilla viitataan yleensä käsitykseen, jonka mukaan matalammat verot, pienempi valtion rooli taloudessa ja tasapainossa oleva valtion budjetti ovat paras lääke valtioita vaivaavaan hitaaseen kasvuun ja velkaantumiseen (Campbell 2009). Uusliberalismin on sanottu saavuttaneen hegemonisen aseman poliittis-taloudellisessa toiminnassa, minkä vuoksi se ohjaa ihmisten ajattelua usein tätä edes huomaamatta (Harvey 2008). Uusliberalismilla voidaan tarkoittaa myös spesifimmin sitä prosessia, jossa markkinoiden ja pääoman vaikutus maailman järjestämiseen lisääntyy ja syvenee, vaikuttaen näin myös yksittäisten ihmisten jokapäiväiseen elämään (Gill ja Cutler 2014).

Gill on nimennyt uusliberalismin poliittis-oikeudellisen ulottuvuuden uudeksi konstitutionalismiksi. ${ }^{2}$ Uusi konstitutionalismi nähdään hallinnointiverkostona, joka pyrkii erottamaan talouspoliittiset linjaukset poliittisesta vastuusta, jotta hallitukset reagoisivat helpommin markkinoiden asettamiin paineisiin ilman pelkoa äänestäjien luottamuksen menettämisestä. Keskeisiä elementtejä uuden konstitutionalismin diskurssissa ovat yksityinen omistusoikeus, sijoittamisen vapaus sekä valtioiden ja työvoiman alistaminen markkinavoimille talouspolitiikan uskottavuuden säilyttämisen nimissä (Gill 1998). Budjettikurisopimus edustaa selkeästi tätä kehityskulkua.

Budjettikurisopimus on oikeudellisena hallintajärjestelmänä yhtäältä luomassa kestävyyden käsitettä, mutta toisaalta myös konkretisoimassa sitä käsitteen soveltamisen kautta. Tässä artikkelissa tarkastellaan budjettikurisopimuksen sisältämää käsitystä kestävyydestä ja sen toimeenpanosta. Artikkeli pyrkii vastaamaan seuraaviin kysymyksiin. Millainen käsitys valtion talouden kestävyydestä sisältyy EU:n talouspoliittisen sääntöjen 
toimeenpanoon ja kuinka tehokasta tämä toimeenpano on? Millaista oikeudellista kehitystä budjettikurisopimus edustaa ja kuinka kestävää kyseinen kehitys itsessään on oikeudellisesti tarkasteltuna?

Artikkelissa esitellään aluksi budjettikurisopimus, jolla pyritään lisäämään valtioiden talouden kestävyyttä. Esittely toteutetaan tarkastelemalla sopimusta osana sitä poliittista ja taloudellista kontekstia, joka johti sen syntyyn, sekä osana unionin talouspoliittisten sääntöjen aiempaa kehitystä. Tässä yhteydessä arvioidaan myös sopimuksen oikeudellista vaikuttavuutta, eli sen mahdollisuutta saada aikaan muutoksia valtioiden toimissa. Tämän jälkeen artikkelissa tarkastellaan, mitä sopimuksen käsityksellä kestävyydestä tarkkaan ottaen tarkoitetaan unionin oikeudellisessa viitekehyksessä. Kestävyyskäsityksen merkitystä arvioidaan osana budjettikurisopimuksen tulkintaa ja soveltamista. Alun kuvailevampien osioiden jälkeen siirrytään analysoimaan millaista oikeudellista kehitystä budjettikurisopimus edustaa ja mitä merkitystä tällä kehityskululla on. Artikkeli tuo esiin sopimuksen ja sen edustaman laajemman talouspoliittisen järjestelmän keskeisiä ongelmia. Johtopäätöksissä arvioidaan, mistä ongelmat johtuvat ja mitä niille voidaan tehdä.

\section{Euroopan talous- ja rahaliitto ja budjettikurisopimus}

Budjettikurisopimus on 25 Euroopan unionin jäsenvaltion kesken solmittu sopimus valtioiden alijäämän ja velkatason vähentämisestä. Sopimuksen osapuolina ovat kaikki muut jäsenvaltiot paitsi Iso-Britannia, Kroatia ja Tšekin tasavalta. Virallisesti sopimuksen tarkoituksena on "vahvistaa osapuolten julkisen talouden hoitamisen kurinalaisuutta ja talouspolitiikkojen yhteensovittamista sekä parantaa talouden ohjausta ja hallintaa Euroopan unionissa ja euroalueella" (HE 155/2012 vp, s. 1). Kyseessä on unionioikeuden ulkopuolella solmittu kansainvälisoikeudellinen sopimus, joka tuli voimaan 1.1.2013. Käytännössä sopimuksella pyritään sisällöllisesti tiukentamaan ja toiminnallisesti tehostamaan jo olemassa olevaa EU:n Vakaus- ja kasvusopimusta.

Sopimus itsessään ja varsinkin sen lopullinen sisältö on monen poliittisen kompromissin summa. Saksan ja Ranskan alkuperäisenä tavoitteena oli ottaa sopimuksen määräykset osaksi unionin primäärioikeutta, mutta 
Ison-Britannian vastustuksesta johtuen tämä ei ollut mahdollista. On arvioitu, että kansallisten äänestäjien miellyttämiseksi päättäjät halusivat kuitenkin saada aikaan jotain näyttävämpää kuin vain uusia direktiivejä tai asetuksia, jollaisia oli jo säädetty samaan asiaan liittyen niin sanotussa six-pack-lainsäädäntöpaketissa, minkä vuoksi päätettiin solmia kansainvälisoikeudellinen sopimus (Craig 2012; Raitio 2012). Sopimukseen sisältyvää velvollisuutta implementoida niin sanottu velkajarru kansalliseen lakiin ei olisi voitu toteuttaa unionin asetusten tai direktiivien perusteella, joten myös tästä syystä erillinen sopimus oli oikeudellisesti ainoa mahdollisuus (Tuori ja Tuori 2014). Kansainvälisoikeudellisen sopimuksen voidaan myös ajatella sitouttavan jäsenvaltioita sääntöjen noudattamiseen vahvemmin kuin unionin yhteisömetodin mukaisesti säädettyjen sekundaarinormien, koska sopimuksen syntyminen edellyttää osallistuvien valtioiden hallitusten yksimielisyyttä ja kansallisten parlamenttien hyväksyntää.

Mikä on sopimuksen taustalta löytyvä Vakaus- ja kasvusopimus? Nimestään huolimatta Euroopan talous- ja rahaliittoon kuuluu tosiasiallisesti ainoastaan yhteinen rahaliitto, mikä muodostuu yhteisvaluutta eurosta ja Euroopan keskuspankin keskitetysti harjoittamasta rahapolitiikasta. Talouspolitiikan, joka voidaan yksinkertaistaen käsittää verotuksesta ja valtion menoista päättämiseksi, osalta kyse on vain jäsenvaltioiden välisestä koordinoinnista eli yhteisten sitomattomien suuntaviivojen ja tavoitteiden laatimisesta. Yhteisvaluutta ja yhteinen rahapolitiikka aiheuttavat jäsenvaltioiden välille voimakkaan riippuvuussuhteen, jota ei kuitenkaan tasapainoteta yhteisellä talouspolitiikalla eli esimerkiksi jäsenvaltioiden välisillä tulonsiirroilla. EMU:n rakenne on näin ollen talouspoliittisesti epäsymmetrinen (Korkman 2013). Ongelma oli päättäjien tiedossa EMU:a suunniteltaessa, mutta Saksa halusi saada yhteisvaluutan aikaiseksi mahdollisimman nopeasti ja oli siksi valmis tinkimään sen lopullisesta muodosta. Saksalaiset saattoivat myös olettaa, että yhteinen talouspolitiikka tulisi luonnollisesti seuraamaan yhteistä rahapolitiikkaa myöhemmin (Garrett 2001). Samaan aikaan laadittiin myös EMU:n niin sanotut lähentymiskriteerit, jotka rahaliittoon mukaan lähteneiden jäsenvaltioiden tuli täyttää ennen euron käyttöönottoa. Viidestä kriteeristä alijäämää ja velkaa koskevat ovat keskeisiä: budjetin alijäämä ei saanut ylittää 3 prosenttia eikä velka 60 prosenttia bruttokansantuotteesta. 
Eurooppa-neuvosto hyväksyi vuonna 1997 päätöslauselman, Vakaus- ja kasvusopimuksen, jossa sovittiin lähentymiskriteerien alijäämä- ja velkarajojen (3/60) noudattamisesta jatkossa ja näihin liittyvistä oikeudellisista mekanismeista. Tälle oli niin poliittisia, taloudellisia kuin oikeudellisia syitä. Taloustieteellisessä kirjallisuudessa oli esitetty, että EMU ei toimisi ilman jonkinasteista talouspolitiikan yhteensovittamista: markkinoiden ei uskottu hinnoittelevan valtioiden lainojen korkoja siten, että vapaamatkustajien ongelmalta vältyttäisiin ilman poliittista ja oikeudellista väliintuloa. Sekä poliitikot että taloustieteilijät väittivät myös, että toimiakseen EMU tarvitsisi joko syvempää talouspoliittista integraatiota tai tiukempaa budjettikuria. Vaikka EMU:n perustaneeseen Maastrichtin sopimukseen kuului oikeudellisia sääntöjä budjettikuriin liittyen, ei näitä pidetty riittävän tehokkaina toiminnan ohjaajina. (Heipertz ja Verdun 2010.)

Vakaus- ja kasvusopimus koostuu kahdesta eri osasta. Euroopan unionin toiminnasta tehdyn sopimuksen (SEUT) 121 artiklan ennaltaehkäisevässä osassa kukin jäsenvaltio asettaa itselleen suunnitelman rakenteellista rahoitusasemaa koskevan julkisen talouden keskipitkän aikavälin tavoitteiksi (medium term objective, MTO). Tämän aikahorisontti on kolme vuotta. Rakenteellisella rahoitusasemalla tarkoitetaan vuosittaista suhdannekorjattua rahoitusasemaa ilman kertaluonteisia ja väliaikaisia toimenpiteitä (budjettikurisopimus 3(3) artikla). Vuotuisissa vakausohjelmissa valtioiden tulee esittää, millä tavalla ne pyrkivät asetettuun tavoitteeseen tai riittävällä nopeudella tavoitteeseen johtavaan sopeutusuraan. Komissio ja Euroopan unionin neuvosto valvovat tavoitteiden noudattamista.

Jos jäsenvaltion todetaan rikkovan asetettuja raja-arvoja, käynnistyy SEUT 126 artiklan korjaava osio, johon sisältyy liiallisia alijäämiä koskeva menettely. Menettelyssä neuvosto antaa jäsenvaltiolle suosituksia toimenpiteistä liiallisen alijäämän korjaamiseksi, pohjautuen komission esitykseen. Suosituksilla pyritään laskemaan BKT:seen suhteutettua alijäämää vähintään 0,5 prosenttiyksikköä vuodessa, jolloin alijäämä lähenisi tavoitetasoa riittävän nopeasti. Annetut suositukset ovat varsin yleisluonteisia (ks. Kreikan kriisin alussa saamat suositukset, Komissio 2009b). Jos alijäämä ei korjaannu ja annettuja ohjeita noudateta, voi neuvosto määrätä jäsenvaltion maksamaan unionille korollisen talletuksen, jonka summa voi olla vuosittain enintään 0,5 \% BKT:sta. Talletus voidaan muuttaa sakoksi, jos liiallinen alijäämä ei ole poistunut kahdessa vuodessa. Liiallisia alijäämiä koskevan 
menettelyn eri vaiheissa päätöksenteko neuvostossa tapahtuu komission esityksestä määräenemmistöllä. 2000-luvun alussa unionin isoimmat jäsenvaltiot rikkoivat Vakaus- ja kasvusopimusta, mutta neuvosto ei langettanut heille sanktioita komission esityksestä huolimatta. Korjaavan mekanismin perustumista poliittiseen päätöksentekoon on pidetty sen heikkoutena (Heipertz ja Verdun 2010).

Budjettikurisopimuksessa sallittavan alijäämän määrää on pienennetty siten, että rakenteellinen alijäämä saa olla enintään puoli prosenttia markkinahintaisesta BKT:sta. Alijäämä saa kuitenkin olla enintään yhden prosentin, jos valtion velka jää merkittävästi alle 60 prosentin viitearvon. Nämä arvot pitää sisällyttää kansalliseen lakiin, jossa tulee myös säätää korjausmekanismista (ns. velkajarru), joka käynnistyy automaattisesti, jos arvoja rikotaan (artikla 3). Perussopimuksissa määriteltyä päätöksentekotapaa liiallisia alijäämiä koskevassa menettelyssä on puolestaan muutettu sopimuksella siten, että neuvosto tekee päätöksen niin sanotulla käännetyllä määräenemmistöllä (artikla 7). Tässä menettelyssä neuvoston jäsenien tulkitaan kannattavan komission esitystä, ellei määräenemmistö jäsenistä nimenomaan äänestä komission esitystä vastaan.

Arviot sopimuksen oikeudellisesta merkityksestä ovat kahtiajakoisia. Sopimuksen sisällöllisten määräysten on sanottu poikkeavan vain vähän jo sen syntyhetkellä voimassa olleesta niin sanotusta six-pack-lainsäädäntöpaketista (Raitio 2012). Sopimuksen mukaan (artikla 3(1)(b)) alijäämä saa olla vain 0,5 \%, kun taas six-packiin kuuluvassa asetuksessa (1175/2011, artikla 2a) raja on 1,0 \% BKT:sta. Sama koskee sopimukseen sisältyvää velkajarrua (sopimuksen artikla 3(2)), jota osittain vastaava säädös löytyy myös six-pack-lainsäädännöstä (asetus 2011/85, artiklat 5-7). Sopimuksen velkajarrun ja asetuksen vastaavien määräysten välistä yhteneväisyyttä on kuitenkin vaikea arvioida, koska velkajarru saatetaan osaksi kansallista lakia eri tavoin eri maissa, kun taas asetusta sovelletaan suoraan kaikissa jäsenvaltioissa. Käännettyyn määräenemmistöön perustuvan päätöksenteon on puolestaan arvioitu poistavan Vakaus- ja kasvusopimuksen täytäntöönpanoon liittyvän poliittisuuden. Komission esitystä on uskottu olevan eritäin vaikea torjua, koska se estää aiemman käytännön, jossa neuvosto ei tehnyt asiassa päätöstä ollenkaan, ja koska päätöksen syntymisen estävän äänimäärän saaminen edellyttäisi kaikkien isojen jäsenvaltioiden olevan asiasta samaa mieltä (Rosas ja Armati 2012). 
Suomessa eduskunta hyväksyy kansainvälisoikeudelliset sopimukset joko yksinkertaisella enemmistöllä tai $2 / 3$ määräenemmistöllä, jos sopimuksen sisällön katsotaan esimerkiksi sitovan eduskunnan budjettivaltaa (perustuslaki 94 S). Eduskunnan perustuslakivaliokunta päätyi arvioinnissaan siihen, että sopimus voidaan hyväksyä yksinkertaisella enemmistöllä siitä huolimatta, että valiokunnan piti "budjettivallan rajoitusta sinänsä merkittävänä”, olkoonkin vähäisenä verrattuna Vakaus- ja kasvusopimuksesta jo johtuviin rajoituksiin (PeVL 37/2012 vp). Kaikki valiokunnassa kuultavana olleet asiantuntijat olivat tällä kannalla. Eriävän mielipiteen jättäneet kolme perussuomalaisten kansanedustajaa korostivat, että demokraattisen legitimiteetin kannalta on ongelmallista sitoa tulevien eduskuntien kädet budjettikurisopimuksen alijäämäsäännöllä ilman, että tämä kirjataan perustuslakiin.

Sopimukseen sisältyvä velkajarru implementoitiin Suomessa tavallisella lailla, josta päätettiin yksinkertaisella enemmistöllä (laki 869/2012). Velkajarru toimii siten, että unionin neuvoston todetessa Suomen ylittäneen sopimuksen raja-arvot tulee valtioneuvoston antaa eduskunnalle perustuslain 44 S:n mukaisen tiedonanto, joka sisältää selostuksen toimenpiteistä, joilla pyritään kohti MTO:ta tai siihen johtavaa sopeutusuraa (lain 3.3. §). Tiedonantoa seuraa hallituksen luottamusäänestys. Mekanismin tarkoitus on siis pyrkiä painostamaan hallitus noudattamaan sopimuksen raja-arvoja siinä pelossa, että muuten se voi kaatua luottamusäänestyksen johdosta. Suomalaiseen käytäntöön kuuluvan vahvan enemmistöhallituksen aikana hallituksen kaatumista tämän takia voi pitää epätodennäköisenä. Toisaalta viime vaalikauden lopussa nähtiin myös erittäin niukka enemmistöhallitus. On siis hyvin epävarmaa, tekisikö neuvosto koskaan edellytetyn päätöksen ja johtaisiko luottamusäänestys koskaan eduskunnan kaatumiseen, minkä vuoksi velkajarrun kansallisen merkityksen voi ainakin Suomen tapauksessa arvioida vähäiseksi.

\section{Kestävyyden määritelmät ja kestävyysindikaattorit}

Kestävyyden retoriikka on laajasti esillä unionin lainsäädännössä. Perussopimukset lähtevät liikkeelle siitä, että valtion talous on kestävä, jos sen budjetissa ei ole yli 3 \% alijäämää (SEUT 126(6) ja 140(1) artiklat). "Kestävä 
maksutase" on myös asetettu yhdeksi unionin ja jäsenvaltioiden toiminnan johtavaksi periaatteeksi (ks. SEUT 119(3) artikla). Kestävyys tuodaan esiin monessa eri merkityksessä myös budjettikurisopimuksessa. Hallitukset sitoutuvat huolehtimaan julkisen talouden "säilymisestä terveenä ja kestävänä" (3 perustelukappale). Tämän lisäksi valtiot uskovat sopimuksen tukevan "kestävää kasvua" (1 artikla) ja mahdollisten alijäämien korjaamista "tehokkaalla ja kestävällä tavalla" (5 artikla). Näiden ja yllä mainittujen EMU:n lähentymiskriteerien perusteella huomaamme, että kestävyyden tulisi olla jotain, mikä on mitattavissa. Miten se tarkalleen ottaen tehdään? Tämän selvittämiseksi on tutkittava Vakaus- ja kasvusopimuksen soveltamiseen liittyviä asiakirjoja.

Komission ensimmäiseen kestävyysraporttiin liittyvässä tiedonannossa tunnistettiin kestävyysvajeen taustalla vaikuttaviksi syiksi väestön määrän ja ikärakenteen muutos, joka johtui alhaisesta syntyvyydestä, elinikäodotusten kasvusta ja suurten ikäluokkien eläkkeelle jäämisestä. Tästä nähtiin seuraavan paineita julkisten menojen kasvuun, joka puolestaan johtaisi ongelmiin "kestävän julkisen talouden ylläpitämisessä pitkällä aikavälillä" (Komissio 2006b, s. 2). Tiedonannon mukaan yksi kestävyyden kannalta keskeisistä ongelmista oli sukupolvien välinen oikeudenmukaisuus eli nykyisten menojen rahoittaminen tulevien sukupolvien maksettavaksi jäävällä lainalla. Poliittiselle agendalle tämä näkemys on noussut ensimmäisen kerran ilmeisesti Eurooppa-neuvoston toimesta jo vuonna 2001 (ks. Eurooppa-neuvosto 2001).

Komission (2006a) ensimmäisessä kestävyysraportissa julkistalouden kestävyys on määritelty valtion velan ja alijäämän kautta. Julkisen velan kestävyys perustuu aikaan suhteutettuun budjettirajoitteeseen. Tämän mukaan nykyinen julkinen velka ja väestön ikääntymisen talousvaikutukset sisältävät tulevat menot pitää pystyä kattamaan tulevilla tuloilla. Jos tähän pystytään, on nykyinen politiikka määritelmällisesti kestävää. Julkisen talouden epätasapainon suuruutta puolestaan arvioidaan käyttämällä kestävy skuiluindikaattoreita. Näillä mitataan kuinka suuria pysyviä sopeutuksia julkiseen talouteen pitää tehdä, jotta budjettirajoitetta pystytään noudattamaan.

Komissiolla on kaksi indikaattoria (S1 ja S2), jotka muodostuvat kolmesta komponentista. Ensimmäinen komponentti on nykyisen budjetin perusjäämän erotus siihen, minkälainen budjetti tarvittaisiin velan määrän vakiinnuttamiseksi eli käytännössä budjetin tasapainottamiseksi siten, että 
tulot riittävät kaikkien menojen ja lainan korkojen kattamiseen. Toinen komponentti kuvastaa kuinka paljon nykyistä budjettia pitäisi sopeuttaa ensimmäisen komponentin lisäksi, jotta tiettynä ajanjaksona saavutettaisiin Vakaus- ja kasvusopimuksen mukainen $60 \%$ velkataso (jos valtion velka ylittää sen nyt). Käytännössä tässä komponentissa on kyse siitä, kuinka nopeaan tahtiin velkaa lyhennetään halutun velkatason saavuttamiseksi. Kolmas komponentti koskee valtion menojen pitkän aikavälin kehityksen vaikutusta budjettivajeeseen. Esimerkiksi väestön ikääntymisen johdosta nousevat eläke- ja terveydenhoitokulut on otettava huomioon tulevaa sopeutustarvetta laskettaessa. Tämä voidaan toteuttaa joko suorilla leikkauksilla ja veronkorotuksilla, tai sitten rakenteellisten uudistusten kautta. Yksinkertaistaen ensimmäinen komponentti mittaa julkisen talouden alkuperäisen rahoitusaseman vaikutuksia ja kolmas komponentti ikääntymisestä aiheutuvia vaikutuksia.

S1-indikaattorissa otetaan huomioon kaikki kolme komponenttia. Toiselle komponentille asetetaan myös tavoiteaika: vuoden 2006 raportissa tämä oli vuosi 2050, vuoden 2009 raportissa se nostettiin vuoteen 2060 ja uusimmassa vuoden 2012 raportissa se on laskettu vuoteen 2030 (Euroopan komissio 2009a ja 2012). S2-indikaattorissa huomioidaan vain ensimmäinen ja kolmas komponentti. Esimerkiksi valtion velan määrän laskemista ei nähdä tässä indikaattorissa relevantiksi, vaikka $60 \%$ ylärajasta voi päätellä, että sopimuksen laatijoiden tavoitteena on kyseistä ylärajaa alempi velkataso. Indikaattorien välinen pitkän aikavälin perusjäämän muutoksista aiheutuva sopeuttamistarve voi poiketa merkittävästi toisistaan. Poikkeama riippuu valitusta aikahorisontista, jonka puitteissa velan tavoitetaso tulisi saavuttaa, ja hyväksytystä valtion velan tasosta suhteessa bruttokansantuotteeseen. S1-indikaattorissa sopeuttamistarve on sitä suurempi mitä lähemmäksi toisen komponentin tavoiteaika asetetaan. S2-indikaattorin ilmoittama sopeuttamistarve voi puolestaan olla erittäin korkea johtuen ikuisuuteen suuntautuvasta aikahorisontista, jossa kulujen oletetaan olevan väestön ikääntymisen johdosta nykyistä korkeammat.

Komissio arvioi valtiontalouden keskipitkän aikavälin kestävyyttä lainan lyhentämisen sisältävällä S1-indikaattorilla, kun taas pitkän aikavälin arviointiin käytetään S2-indikaattoria. Sittemmin komissio on kehittänyt myös lyhyen aikavälin arviointiin käytettävän S0-indikaattorin, joka pyrkii arvioimaan seuraavan vuoden aikana tapahtuvia talouden äkillisiä heilahduksia 
markkina-analyysiin perustuen. Komission (2012) mukaan eurokriisin tapahtumat ovat osoittaneet tällaisen indikaattorin tarpeelliseksi.

Laine (2010, s. 42) on tiivistänyt indikaattorien käytännön merkityksen hyvin: "Kestävyysindikaattoreiden jaottelu kolmeen komponenttiin auttaa ymmärtämään, mitkä tekijät ovat kestävyysvajeiden takana, mitkä politiikkavaihtoehdot sopivat kuhunkin tilanteeseen ja kuinka kiireellistä kestävyysvajeeseen puuttuminen on". Komissio (2006a) korostaa, että indikaattorit eivät ole preskriptiivisiä, eli ne eivät itsessään sano millaisia toimia pitäisi tehdä tavoitteeksi asetetun alijäämä- tai velkatason saavuttamiseksi. Käytettävissä olevat keinot ovat komission mukaan verojen korotus, välitön menojen leikkaus tai sopeutustoimet, jotka johtavat pitkällä aikavälillä menojen laskuun ja/tai verotulojen nousuun.

Komission (2012) mukaan toisen komponentin nykyinen aikahorisontti (vuosi 2030) on valittu sen perusteella, että se mahdollistaa ikääntymisen aiheuttamista menoista johtuvan sopeuttamisen asteittain - kuitenkin siten, että se pysyy nykyisten päättäjien ja veronmaksajien näkökentässä. Lisäksi valittu aikahorisontti on yhtenevä six-pack-säännöstöön ja budjettikurisopimukseen sisältyvien sitoumusten kanssa. Vaikka indikaattorit eivät ole suoraan preskriptiivisiä, vaikuttaa niiden muotoilu - erityisesti velan lyhentämiselle asetettu tavoiteaika - suoraan siihen, kuinka iso havaittu kestävyysvaje on ja kuinka suuria sopeutustoimia sen korjaamiseksi tarvitaan. Mitä nopeampaan sopeutus tulee tehdä, sitä rajallisemmat ovat käytettävissä olevat keinot: menojen leikkaus ja verojen korotus toimivat välittömästi toisin kuin rakenneuudistukset, joiden mahdolliset vaikutukset näkyvät vasta myöhemmin.

Komissio käyttää kestävyysindikaattoreita niin sanotun eurooppalaisen ohjausjakson (EU:ssa toteutettava talous- ja finanssipolitiikan koordinaatiosykli, ks. asetus 473/2013) aikana kansallisten vakaus- ja kasvuohjelmien arvioinnissa ja maakohtaisten suositusten laatimisessa. Niiden merkitys EU:n talouspoliittisten sääntöjen toimeenpanossa on kuitenkin hyvin vähäinen ainakin verrattuna siihen, millaisen käsitys kestävyyden merkityksestä annetaan budjettikurisopimuksen 3 artiklassa. Normaali keskipitkän aikavälin tavoitteisiin tähtäävä lähentymistahti on rakenteellisen rahoitusaseman parantaminen 0,5 \% BKT:sta verran vuodessa. Lähentymisaikataulua laatiessaan komissio (2013) kuitenkin edellyttää valtioilta, joiden velkataso ylittää $60 \%$ raja-arvon tai joiden velkatason kehitystä pidetään 
kestämättömänä yli $0,5 \%$ vuotuista muutosta. Velkatason kestämättömyyden arvioinnissa käytetään apuna S1-indikaattoria. Jos valtion velkataso on toisin sanoen kestämätön S1-indikaattorin mukaan, tulee sen lähentyä MTO:ta yli 0,5\% vuotuisella muutostahdilla. Valtiontalouden tarkastusvirasto, joka valvoo Suomessa Vakaus- ja kasvusopimuksen noudattamista, ei ole vielä soveltanut indikaattoria hyödyntävää kestävyysarviointia. Tämä johtuu siitä, että Suomen talous on ollut viraston tulkinnan perusteella sopimuksen asettamien kriteerien valossa niin hyvässä kunnossa, ettei tähän ole ollut tarvetta (Valtiontalouden tarkastusvirasto, 2015).

Valtiontalouden kestävyys on määritelty numeerisin kriteerein. Näin ollen molempia sopimuksia lukuisine viittauksineen kestävyyteen pitäisi pystyä soveltamaan tältä osin selkeästi ja objektiivisesti määritellyllä tavalla. Kestävyyden merkitys sopimusten soveltamisessa näyttää kuitenkin jäävän oikeudellisesti vähäiseksi. Mikä budjettikurisopimuksen merkitys sitten on, jos sen muodollinen ja sisällöllinen vaikutus on oikeudellisesti vähäinen?

\section{Kestävyys oikeuden ja politiikan rajapinnalla}

Oikeudellisten rakenteiden käyttö osana kansainvälistä talouspoliittista hallintaa on yleistynyt tämän vuosituhannen aikana niin kutsutun uuden konstitutionalismin nousun myötä. Uudella konstitutionalismilla on viitattu kirjallisuudessa moniin eri asioihin, kuten kansainvälisten oikeudellisten rakenteiden luomiseen, vallan siirtymiseen tuomioistuimille tai virkamiehille, tai vallan rajoittamiseen ja hallinnointitapojen kehittämiseen. Monet eri prosessit lisäävät tätä kehityskulkua, mutta tämän artikkelin aihepiirin kannalta keskeisin kehityskulku on se, millaiseksi talouden instituutioiden asema säädetään oikeudellisesti. Olennaista tässä kehityskulussa on sen hahmottaminen, että uusi konstitutionalismi poliittisen talouden hallintorakenteena pohjaa sekä kansallisen tason valtiosääntöoikeudellisille muutoksille että kansainvälisen talouden etenevälle liberalisaatiolle (Gill ja Cutler 2014). Näitä kansallisia ja kansainvälisiä hallintorakenteita muokkaamalla uusliberalismi on institutionalisoitu poliittis-taloudelliseen vallankäyttöön makrotasolla. Tämä tapahtuu erityisesti talouspolitiikkaan suuntautuvilla "sitovilla" rajoitteilla, jotka eristävät päätöksenteon politiikoista ja 
kansalaisista (Gill 1995).

Budjettikurisopimus näyttää tämän kuvauksen perusteella olevan malliesimerkki uusliberaalista talouspolitiikasta ja uuden konstitutionalismin mukaisista valtarakenteista. Uusliberaalin talouspolitiikan ihanteen mukaisesti sopimus pyrkii kitkemään valtioiden talouksien alijäämät ja suitsimaan niiden velkaantumista. Syyksi tälle on ilmoitettu kestävyysvajeeseen puuttuminen, jonka mielekkyys politiikan tavoitteena on vähintään kyseenalainen (ks. Sorsa 2014). Sopimuksen laatijat pystyvät kehystämällä sopimuksen kestävyyden retoriikalla hyödyntämään kestävyyden politiikkaideaan sisältyvän positiivisen mielleyhtymän (Cox ja Béland 2013), vaikka sopimuksen todellisesta hyödyistä ei olisikaan takeita. Salmisen (2013, 1093) mukaan sopimuksen raja-arvot ja velkajarru ovat "yritys kansainvälisen sopimuksen keinoin tehdä näkyväksi unionijäsenvaltioiden sidottuisuutta toisiinsa". Näin varmasti on, mutta tarkoittaako tämä "sidottuisuus" jonkinlaista solidaarisuutta jäsenvaltioiden välillä vai onko se vain ilmentymä uuskonstitutionaalisesta hegemoniasta, jolla pyritään hallitsemaan ja ohjaamaan jäsenvaltioiden talouspolitiikkaa?

Ylempänä totesin, että sopimuksen itsensä suora oikeudellinen merkitys on vähäinen. Sopimuksen merkitystä pitää kuitenkin arvioida osana EU:n uutta finanssipoliittista rakennetta. Kriisivaltioille rahoitusapua myöntävän Euroopan vakausmekanismin (EVM) sääntöjen mukaan apua voi saada vain, jos on allekirjoittanut budjettikurisopimuksen. Sen lisäksi avunsaajan on myös hyväksyttävä niin sanottu yhteisymmärryspöytäkirja, jossa sovitaan erittäin yksityiskohtaisista uudistuksista, joita valtion on tehtävä vastineeksi avusta. Yhteisymmärryspöytäkirjat ovat erittäin preskriptiivisiä, vaikka budjettikurisopimus tai kestävyysarvioinnit eivät sitä olisikaan (ks. Euroopan komissio 2015).

Budjettikurisopimus pyrkii hyödyntämään taloudellisen päätöksenteon teknokratisointia, apolitisointia ja jopa automatisointia. Vaikka budjettikurisopimuksen teksti itsessään tuntuu helposti ymmärrettävältä, kätkeytyy sen taakse monimutkainen ja vaikeasti käsitettävä EU:n finanssipoliittisen päätöksenteon sääntelykehikko. Finanssipoliittisten sääntöjen soveltamisessa keskeisessä asemassa ovat erilaiset laskentamallit, joiden perusteella komissio laatii omat arvionsa ja suosituksensa. Koska sopimuksessa valtion velkataso ja budjettialijäämä suhteutetaan aina bruttokansantuotteeseen, riippuvat sopimuksesta johtuvat velvoitteet arvioidusta potentiaalisesta BKT:sta ja sen 
kasvuvauhdista. Komission käyttämiä laskentamalleja on kritisoitu siitä, että ne johtavat itse asiassa myötäsykliseen finanssipolitiikkaan, mikä on haitallista kriisien ratkaisun kannalta. Ongelman voisi Hetemäen (2015) mukaan korjata vaihtamalla komission käyttämää laskentamallia. Näin teknokraattinen päätöksenteko vaikuttaa konkreettisesti siihen, millaisia lopputuloksia sopimus tuottaa ja millaista talouspolitiikka valtiot joutuvat harjoittamaan.

Asettamalla numeraalisia finanssipoliittisia tavoitteita budjettikurisopimus johtaa helposti seuraavanlaiseen ajattelumalliin: "koska alijäämä on liian korkea, meidän täyty leikata" tai "koska emme lähentyneet MTO:tta riittävän nopeasti, meidän täytyy leikata enemmän”. Sopimus tuottaa täten poliittiseen päätöksentekoon vaihtoehdottomuutta, joka heikentää mahdollisuutta demokratian kannalta oleelliseen kriittiseen arviointiin (Eskelinen ja Sorsa 2011). Sopimuksen solmiminen ja kansallinen hyväksyntä oli poliittinen päätös, mutta tämän jälkeen ei ole enää tarvetta politisointiin, sillä sopimus itsessään osoittaa politiikan oikean sisällön - siitäkin huolimatta, että komissio korostaa, ettei kestävyyslaskelmien tuottama tieto ole preskriptiivistä.

Kolmas budjettikurisopimuksen uuskonstitutionalistinen piirre on automatisointi. Käännetyn määräenemmistöpäätöksenteon omaksuminen neuvostossa pyrkii nimenomaan siihen, että Vakaus- ja kasvusopimuksen ennaltaehkäisevän ja korjaavan osan toimeenpano automatisoituisi. Tällöin päätöksenteosta poistuisi poliittinen harkinta ja se perustuisi vain komission teknokraattiseen arvioon. Myös kansallisiin lakeihin otettu velkajarru tähtää samaan. Kansallista velkajarrua säädettäessä Suomen hallitus argumentoi, että velkajarru on hyvä keino sitouttaa koko eduskunta hallituksen talouspoliittiseen linjaan ja täten parantaa talouspolitiikan legitimiteettiä (HE 155/2012 vp). Asialla on kuitenkin myös toinen puoli: velkajarru laukaisee luottamusäänestyksen nimenomaan neuvoston päätöksen johdosta, joka perustuu komission teknokraattien esitykseen ja joka on automatisoitu uudella äänestysmenettelyllä.

Myös itse kestävyysindikaattorit ja niiden käyttö sisältävät uuskonstitutionalistisia piirteitä. Indikaattorien näennäinen tieteellisyys ei poista sitä faktaa, että niillä tavoiteltu alijäämä ja velkataso on itsessään valittu mielivaltaisesti. Toisaalta ne voidaan indikaattorien vähäisen käytännön merkityksen johdosta tulkita enemmänkin yrityksenä teknokratisoida ja tieteellistää asiaa, jossa on oikeasti kyse sisällöllisistä poliittisista valinnoista. 
Sopimuksen neuvotteluvaihe - joka monien kompromissien kautta johti alkuperäistä tavoitetta lievemmin muotoiltuun sopimukseen (Craig 2012) - tarjoaa hyvän esimerkin siitä, miten oikeus ja oikeudelliset instituutiot voivat myös vaikuttaa uuskonstitutionaalisen paradigman vastaisesti. Suomen eduskunnan perustuslakivaliokunnan kannanotoilla sopimusluonnoksen eri versioista on arvioitu olleen vaikutusta sopimuksen lopulliseen sisältöön (Tuori ja Tuori 2014). Perustuslakivaliokunta piti ongelmallisena erityisesti sitä, että sopimuksen sisältö olisi tullut alkuperäisen idean mukaisesti kirjata kansalliseen perustuslakiin ja että kansallisille tuomioistuimille annettaisiin valta valvoa sopimuksen noudattamista (ks. PeVL 37/2012 vp ja PeVL 24/2011 vp). Molemmat seikat jäivät pois sopimuksen lopullisesta versiosta.

Lailla ja laajemmin oikeudella on ollut keskeinen merkitys Euroopan integraation kannalta. Kuten Dehousse ja Weiler (1990) ovat osoittaneet, laki on samalla sekä integraation kohde että sen agentti. Tällä he tarkoittavat sitä, että integraatiota edistetään käytännössä yhtenäistämällä kansallisia lakeja, mutta oikeus on myös edistänyt integraatiota silloin, kun poliittista tahtoa tähän ei ole löytynyt. Käytännössä tämä on tapahtunut unionin tuomioistuimen unionin perusvapauksien sisältöä laajentavasti tulkitsevan oikeuskäytännön kautta, joka on sittemmin hyväksytty kansallisella tasolla (ks. Maduro 1998). Mielestäni Vakaus- ja kasvusopimuksen historia osoittaa, että oikeus on jälleen mahdollistamassa integraation syvenemisen alueelle, jota ei ole poliittisesti päätetty harmonisoida. Vaikka unionilla ei vielä ole yhteistä talouspolitiikkaa, on yhteinen rahapolitiikka kuitenkin johtanut talouspolitiikkaan liittyvän sääntelyn asteittaiseen tiukentamiseen. Näin funktionaalinen yliläikkyminen (spillover) yhteisestä rahapolitiikasta on johtamassa kohti yhteistä talouspolitiikkaa käyttäen apunaan oikeudellisia mekanismeja, kuten budjettikurisopimusta. Ehkä nyt onkin tapahtumassa se, mitä saksalaiset olettivat jo kaksikymmentä vuotta sitten.

Kuten Saari (2013) on huomioinut, budjettikurisopimuksen vaikutukset ulottuvat myös sosiaali- ja terveyspolitiikan alalle, jolla unionilla ei ole toimivaltaa, koska sopimuksen raja-arvojen tiukka noudattaminen johtaa monissa valtioissa nimenomaan näihin kohdistuviin leikkauksiin. Erityisesti S1-indikaattorin tavoitetason ajankohdan lyhentäminen vuoteen 2030 lisää tätä vaikutusta. Viime vuosituhannella tapahtunut unionin perusvapauksien laajentuminen tai ihmisoikeuksien tuominen osaksi unionin 
oikeusjärjestystä eräänlaisen yliläikkymisen takia EU-tuomioistuimen toimesta oli perusteltua siksi, että ensimmäiset oli kirjattu unionin perussopimukseen ja ihmisoikeudet kaikkien jäsenvaltioiden perustuslakeihin. Yhteisen rahapolitiikan johtamista yhteiseen talouspolitiikkaan ei kuitenkaan voida oikeuttaa samanlaisilla perusteilla, koska Maastrichtin sopimuksella luotuun talous- ja rahaliittoon ei nimenomaan kuulu yhteinen talouspolitiikka. Yhteisen talouspolitiikan perustamiselle ilman eksplisiittistä poliittista päätöstä ei myöskään löydy oikeutusta kansallisista perustuslaeista tai unionin yleisistä arvoista tai tavoitteista. Myös budjettikurisopimuksen tämä ulottuvuus kuvastaa sitä, kuinka eurokriisin seurauksena unionin oikeudellisesti hallittu talouspoliittinen järjestelmä kehittyy uuden konstitutionalismin premissien mukaisesti.

\section{Johtopäätökset}

Kaiken kaikkiaan vaikuttaa siltä, että budjettikurisopimuksesta itsestään ja sen yleisemmästä merkityksestä tehtävät johtopäätökset ovat osittain ristiriitaisia. Tarkastelu on osoittanut sopimuksen vahvistavan uuskonstitutionalistista kehitystä unionissa ja tuonut esiin tähän liittyviä ongelmia. Vaikka sopimuksen oikeudellinen merkitys arvioitiin käytännössä vähäiseksi, ja vaikka se ei suoranaisesti saisikaan aikaan muutoksia, kertoo jo pelkkä sopimuksen laatiminen siitä, millaiseen talouspolitiikkaan poliitikot uskovat. Tämä usko heijastuu varmasti talouspolitiikan sisältöön myös suoraan ilman sopimuksen mahdollista välittävää vaikutusta.

Budjettikurisopimus, jolla näennäisesti pyritään ohjaamaan valtiot kestävän talouspolitiikan harjoittamiseen, on siis todellisuudessa yritys naamioida tietty poliittinen valinta neutraalina tarjottuun normatiivisuuden kaapuun. Sopimuksen laatijat pyrkivät siten ulkoistamaan politiikan tekemisen oikeudellisiin mekanismeihin (ennaltaehkäisevä ja korjaava osio sekä kansalliset velkajarrut). "Kestävyyden" lisäämiseen on näin saattanut toimia hyvänä sumuverhona muihin ideoihin ja intresseihin perustuvien rakenneuudistusten tekemiselle.

EMU:n epäsymmetriaa on luonnehdittu yhdeksi kriisiin johtaneista syistä ja se on myös vaikuttanut kriisinhoitomekanismien, kuten budjettikurisopimuksen muotoiluun. Epäsymmetrian taustalla oli halu pitää poliittisesti 
tärkeäksi koettu talouspoliittinen päätäntävalta legitiimiksi koetun kansallisen parlamentin käsissä. Yllä kuvattu uuskonstitutionalistinen kehitys on kuitenkin johtanut juuri vastakkaiseen lopputulokseen. Ongelma voidaan korjata poistamalla EMU:n epäsymmetria luomalla aito talousliitto. Jos yhteisvaluutta halutaan säilyttää, tulisi sen rinnalla olla demokraattiseen päätöksentekoon perustuva yhteinen talouspolitiikka, johon kuuluisi myös budjettivalta (ks. Eskelinen ja Sorsa 2011). Mielestäni tämän tekeminen pitäisi tapahtua suoralla poliittisella päätöksellä, eikä epäsuorasti talouspoliittista kontrollia lisäten, kuten budjettikurisopimuksen keinoin. Habermasia (2012) lainaten budjettikurisopimus lisää valtioiden välistä integraatiota oikeudellisena mekanismina, mutta se ei lisää kansalaisten välistä integraatiota, joka voidaan tehdä vain demokraattista osallistumista kehittämällä.

Tämän ratkaisumallin ongelma on kuitenkin sama kuin budjettikurisopimuksen syntymisen taustalla vaikuttanut syy: poliittisen tahdon puute integraation lisäämiseen. Kansallisen budjettisuvereniteetin sekä demokraattisen osallistumisen ja oikeutuksen näkökulmasta unioni on siis melkoisen paradoksin edessä. EMU:n epäsymmetrinen rakenne on poliittisesti kestämätön samoin kuin se tapa, jolla budjettikurisopimus pyrkii ratkaisemaan tämän ongelman oikeudellisesti. Pyrkimys lisätä talouden kestävyyttä oikeudellisesti on siis loppuen lopuksi vain päätynyt paljastamaan unionin oikeudellisen rakenteen kestämättömyyden.

\section{Viitteet}

I) Virallisissa yhteyksissä sopimusta kutsutaan yleensä finanssipoliittiseksi sopimukseksi tai vakaussopimukseksi, mutta mielestäni nimi budjettikurisopimus kertoo paremmin mistä sopimuksessa on todella kyse.

2) New constitutionalism on yleensä suomennettu uudeksi perustuslaillisuudeksi (ks. Gill 2011), mutta mielestäni uusi konstitutionalismi on parempi käännös, sillä englanninkielinen alkutermi viittaa nimenomaan doktriiniin ja prosessiin (konstitutionalismi), eikä niinkään yksittäiseen normatiiviseen asiakirjaan (perustuslaki). 


\section{Lähteet}

Campbell, John. 2009. What do sociologists bring to IPE?. Teoksessa Mark Blyth (toim.), Routledge handbook of international political economy (IPE). IPE as a global conversation. Oxford: Routledge, 266-279.

Cox, Robert Henry ja Béland, Daniel. 2013. Valence, policy ideas, and the rise of sustainability. Governance: An International Journal of Policy, Administration, and Institutions, 26:2, 307-328.

Craig, Paul. 2012. The Stability, coordination and governance treaty: principle, politics and pragmatism. European Law Review, 37:3, 231-248.

Dehousse, Renaud ja Weiler, Joseph. 1990. The legal dimension. Teoksessa William Wallace (toim.), The dynamics of European integration. Lontoo: Pinter, 242-260.

Eskelinen, Teppo ja Sorsa, Ville-Pekka. 2011. Hyvä talous. Helsinki: Like.

Euroopan komissio. 2006a. The long-term sustainability of public finances in the European Union. European Economy No. 4. Brussels: European Commission, Directorate-General for Economic and Financial Affairs.

Euroopan komission. 2006b. KOM(2006) 574 lopullinen, Komission tiedonanto neuvostolle ja Euroopan parlamentille, Julkisen talouden pitkän aikavälin kestävyys EU:ssa.

Euroopan komissio. 2009a. Sustainability Report 2009. European Economy No. 9. Bryssel: European Commission, Directorate-General for Economic and Financial Affairs.

Euroopan komissio. 2009b. SEC(2009) 565 final, Recommendation for a council recommendation to Greece with a view to bringing an end to the situation of an excessive government deficit.

Euroopan komissio. 2012. Fiscal sustainability report 2012. European Economy No. 8. Brussels: European Commission, Directorate-General for Economic and Financial Affairs.

Euroopan komissio. 2013. Vade mecum on the Stability and Growth Pact. 
Occasional Papers 151. European Commission, Directorate-General for Economic and Financial Affairs, Bryssel.

Euroopan komissio. 2015. Press release: Commission signs three-year ESM stability support programme for Greece. 20.8.2015, Bryssel.

Eurooppa-neuvosto. 1997. Päätöslauselma vakaus- ja kasvusopimuksesta. EYVL C 236, 2.8.1997, s. 1-2.

Eurooppa-neuvosto. 2001. Puheenjohtajan päätelmät Tukholman Eurooppaneuvosto 23. ja 24. maaliskuuta 2001. Komission lehdistötiedote C/01/900.

Garrett, Geoffrey. 2001. The politics of Maastricht. Teoksessa Barry Eichengreen ja Jeffry A. Frieden (toim.), The political economy of European monetary unification. Toinen painos. Boulder, Colorado: Westview Press, 111-130.

Gill, Stephen. 1995. Globalisation, market civilisation, and disciplinary neoliberalism. Millennium, 24:3, 399-423.

Gill, Stephen Gill. 1998. European governance and new constitutionalism: economic and monetary union and alternatives to disciplinary neoliberalism in Europe. New Political Economy, 3:1, 5-26.

Gill, Stephen. 2011. Valta ja vastarinta uudessa maailmanjärjestyksessä. Suomentanut Timo Soukola. Helsinki: Gaudeamus.

Gill, Stephen ja Cutler, A. Claire. 2014. New constitutionalism and world order: general introduction. Teoksessa Stephen Gill ja A. Claire Cutler (toim.), New constitutionalism and world order. Cambridge: Cambridge University Press, $1-22$.

Habermas, Jürgen. 2012. Bringing the integration of citizens into line with the integration of states. European Law Journal, 18:4, 485-488.

Harvey, David. 2008. Uusliberalismin lyhyt historia. Suomentanut Kaisa Koskinen. Tampere: Vastapaino.

Heipertz, Martin ja Verdun, Amy. 2010. Ruling Europe: the politics of the Stability and Growth Pact. Cambridge: Cambridge University Press.

Hetemäki, Martti. 2015. Eurokriisin syyt ja euroalueen tulevaisuus. Kansantaloudellinen aikakauskirja, 111:1, 16-39. 
Korkman, Sixten. 2013. EURO. Valuutta vailla valtiota. Helsinki: Taloustieto Oy.

Laine, Veli. 2010. Julkisen talouden pitkän aikavälin kestävyys Euroopan unionissa. Talous \& Yhteiskunta, 38:2, 41-48.

Maduro, Miguel Poiares. 1998. We the court. The European Court of Justice and the European economic constitution: a critical reading of article 30 of the EC treaty. Oxford: Hart Publishing.

Raitio, Juha. 2012. Ajankohtaiskatsaus Euroopan velkakriisistä: ERVV, EVM, Kasvu- ja vakaussopimus sekä Sopimus talousunionin vahvistamisesta. Defensor Legis, 2/2012, 254-260.

Rosas, Allan ja Armati, Lorna. 2012. EU constitutional law: an introduction. 2nd revised edition. Oxford: Hart Publishing.

Saari, Juho. 2013. Julkinen talous ja sosiaalimenot. Teoksessa Tapio Raunio ja Juho Saari (toim.), Euroopan paras maa? Suomen muuttuva asema Euroopan unionissa. Kuopio: Gaudeamus, 62-88.

Salminen, Janne. 2013. Sopimus talous- ja rahaliiton vakaudesta - tie fiskaaliunioniin? Lakimies, 6/2013, 1076-1098.

Sopimus talous- ja rahaliiton vakaudesta, yhteensovittamisesta sekä ohjauksesta ja hallinnasta. Eurooppa-neuvosto, 30.1.2012. (HE 155/2012 vp liitteenä)

Sorsa, Ville-Pekka. 2014. Kestävyysvajeen politiikkaidean kritiikki. Politiikka, $56: 2,132-142$.

Tuori, Kaarlo ja Tuori, Klaus. 2014. The eurozone crisis: a constitutional analysis. Cambridge: Cambridge University Press.

Valtiontalouden tarkastusvirasto. 2015. Vakaus- ja kasvusopimuksen noudattamisen tarkastus 2014. Tarkastusmuistio. Dnro 197/51/2013, 22.5.2014. 